\title{
Increasing Public Interest on Reading through Physical and Digital Library in Karangmojo Village
}

\author{
Ratna Widyaningsih"1, Yudhy Widya Kusumo², Ristiyan Ragil Putradianto3 ${ }^{3}$ Dewi Nur \\ Khasanah ${ }^{4}$, Intan Zuhaira ${ }^{5}$
}

\begin{abstract}
The current Covid-19 pandemic obliges children to study online. It requires children to use gadgets either smart hand phone or laptop. It makes a big increasing gadgets utilization. A lot of children spend their time just playing 'online games'. Adults who do activities or work from home on average spend their time using gadgets. With this phenomenon, people's interest in reading has decreased. One way to increase people's interest in reading is by making the Karangmojo Village Community Reading Corner. In the current era of globalization, this Community Reading Corner not only provides a physical library but also provides a digital library that can be accessed via the web by the people of Karangmojo Village.
\end{abstract}

Keywords: community reading Corner, physical library, digital library

This is an open access article under the CC-BY-NC license

\section{INTRODUCTION}

Childhood and youth are the most appropriate time to hone one's abilities and character. A good formal education and/or skill learning, an intense mentoring, and the availability of educational support facilities are needed factors to help children achieve the competence optimally. Broad insight is also one of the things that is expected from the existence of these supporting factors. Children will grow up to be someone who has competence in their field and is broad-minded. These two things become part of a person's provision to become and be able to compete in this era of globalization.

In this era of globalization, education is very important. Because education is the root of a nation's civilization. There are many ways to get education, including through the library. In this library, you can get various sources of information, one of which is by reading. Reading is a very good way to add insight, increase vocabulary and improve science and technology.

In the Law of the Republic of Indonesia Number 43 of 2007 Article 3 concerning Libraries, it is stated that the function of the library is as a vehicle for education, research, preservation, information and recreation to increase the intelligence and empowerment of the nation. With the functions possessed by the library, including as a vehicle for education and an information centre, the library must be supported by devices that can make it easier to find the information needed.

The existence of a library at least provides a role for the wider community to be able to provide reading materials and provide facilities for the development of knowledge. Not everyone can afford to buy books, especially for most of our society, the consumption of books is the umpteenth need compared to other needs. So, what is needed is the spirit of curiosity and reading in order to be able to take advantage of all the knowledge that is in the library.

Digital libraries are an option to create a pocket-friendly library for the wider community. Digital Library is an alternative that can be done by libraries to improve their library services. Because with this digital system, libraries can format available information from printed formats to electronic or digital formats. This is the answer for users who want information that is packaged in a concise, concise and accurate manner. Ideally, every library utilizes the sophistication of information technology to support the management of library collections. 
Digital libraries are created using a Web system. The public can download or upload books in .pdf format which can be accessed via smartphones or existing PCs. Not only adults, but children who have been facilitated by smartphones can access them to find the books they need. Although the Web system is still paid, the community can use village funds or joint contributions so that the money spent is still not as much as if they bought physical books.

Library is the one of main role in transfering knowledges or educational matters. It has various kinds of books and journals from various disciplines. The books are provided in this program not only learning resources for children or students, but also a special program in providing learning resource services for people from various circles. In this case, the community reading corner is one of the educational services that can be utilized by the community in developing and improving a reading culture.

\section{RESEARCH METHODS}

The team had previously met with partners which is represented by Dukuh of Karangmojo Village, where the team and partners agreed to support each other in the implementation of this activity. This is indicated by a letter of willingness to support partners for this activity. Partners will facilitate the location for the provision of Karangmojo Village Community Reading Corner. The team takes the following steps in the implementation of this activity, namely:

1. Survey

This activity is done to determine the condition of the location that will be chosen as a community reading corner. The location chosen should be easily accessible location and could be well maintained.

2. Material Collection and Preparation

Team collects some informations about the partner's social condition. The informations are such as the amount of people with the certain age and occupation. It aims to helps creating a community reading corner that is in accordance with their condition.

3. Inventory

The team make a list about the facilities and infrastructure that were already available and needed to create this reading corner.

4. Procurement and Construction of Facilities at TBM

The team procures books that are adapted to their content which includes Indonesian folk tales, general knowledge, expertise, religion. Procurement of bookshelves and book lending system. The borrowing system is carried out with a schedule considering that there is a pandemic, so it needs to be done according to health protocols. This activity involves youth organizations and the community in Karangmojo Village.

5. Procurement and Construction of Digital Library Facilities

The team procures online books that are adapted to their content which includes Indonesian folk tales, general knowledge, expertise, religion. The procurement of this digital library utilizes the Web as a means for the community to access the books that have been provided.

6. Socialization, Implementation, Monitoring and Evaluation

After the preparation of the system is ready to run, then socialization is carried out to the community through information from the local Village. Implementation is carried out and monitoring and evaluation continue to be carried out to improve this activity.

7. Submission of TBM to Village Karangmojo

The results of this activity were handed over to the Karangmojo Village community and the management was handed over to the local community. This is done so that the continuity of activities after being handed over to Karangmojo Village.

8. Reporting, Publication and Registration of IPR and product ISBNs 
After the activity is completed, documentation, mandatory outputs and reports are collected

to be compiled and submitted to LPPM UPN "Veteran" Yogyakarta.

\section{RESULTS AND DISCUSSION}

The Karangmojo Village Community Reading Corner is located in the courtyard of the An-Nur Mosque in Karangmojo Village, Purwomartani Village, Kalasan District, Sleman Regency, DI Yogyakarta Province. Locationthis is the result of discussions with the head of the village and the mosque management. This location is the most frequented place by the community and is in the middle of Karangmojo Village, also has facilities for reading on the spot and has a large parking area and a good environment for reading. The reading environment greatly affects people's reading interest.

According to Sutarno (2008:127) Community Reading Park is basically not a library that must meet the national library standards such as collection standards, facilities and infrastructure standards, library service standards, library staff standards, management standards, and management standards. Community Reading corners is an institution that provides reading materials needed by the community as a place for organizing reading and learning skills development. In addition to borrowing and reading books, Community Reading corners will be used as a place for productive activities.

Community Reading corners as a medium for developing a reading culture is a place to access various reading materials, such as textbooks, practical skills books, knowledge books, religious books, entertainment books, literary works and other reading materials that are in accordance with the objective conditions and needs of the surrounding community and interest in reading, both for new literates, students of the Formal and Non-Formal Education pathways (learning residents), as well as the general public without age limit. In the Guidelines for the Implementation of Community Reading corners (2006:9), it is stated that Community Reading corners is a place or container established and managed, both by the community and the government to provide access to reading material services to the surrounding community as a means of lifelong learning in order to improve the quality of life. Community life around Reading corners. Sutarno (2008:127) also explained that Community Reading corners is more accurately referred to as a reading facility located in the midst of a community (community based library) and is managed in a simple, self-sufficient, self-funding and self-sufficient manner by the community concerned. In this case, it is necessary to develop a sense of belonging and a sense of responsibility.

In the guidebook for the Management of Community Reading corners (2006:2), it is explained that the function of Community Reading corners is as (1) a learning tool for the community to learn independently and to support the curriculum for the Out-of-school Education program, especially the literacy program; (2) sources of information sourced from various books and other reading materials in accordance with the needs of learning residents and the local community; (3) research sources (library studies) by utilizing books and various other available reading materials, (4) reference sources that provide reference materials for learning and other academic activities; (5) sources of entertainment (recreational) that provide reading materials that are recreational in nature to take advantage of free time to gain new knowledge/information that is interesting and useful.

The provision of physical books for Community Reading corners Karangmojo village is done by buying books at several bookstores in Yogyakarta. Then the team gave the cover and made an inventory and grouped the existing book categories. Community Reading corners Karangmojo Village provides 350 physical books which are grouped into six categories, namely Children's Books, Natural Knowledge, General Knowledge, Religion, Entrepreneurship, and Archipelago Insights. It is hoped that the grouping of these book categories will make it easier for people to find and borrow books. Children can also pick up children's category books without having to search from other book categories. 
The physical book lending system can be done online with an application called Handy Library. This application is very easy to use by admins or administrators of Community Reading corners Karangmojo village to record books that are being or have been borrowed by the community. Admin can write down the borrower's name and membership number as well as the status of the book loan. The Handy Library app allows scanning the ISBN and obtaining details of a book, reading it and even lending it online. In addition, the Handy Library application also has features such as easy search for books to get the title, author and ISBN code online.

The provision of a Digital Library for Community Reading corners Karangmojo village is in the process of creating a web and training web admins for the existing community or Karangtaruna. The system of this digital library is that people can download books that have been provided with .pdf document files or can be read online by the public. The use of the web system itself requires a monthly payment. This payment can be made using village funds or joint contributions raised by the community. This web system digital library can be used as long as possible as long as the web system payment is still made. The team develops web design, borrowing techniques, book management techniques, and web development. The management of the web is then left to the admin or administrator of Community Reading corners Karangmojo village.

As a program, of course, Community Reading corners Karangmojo village should be able to carry out its function as a medium or vehicle that can become a center for information services in the development of science and as a stimulus (stimulation) for the formation of people who like to read, namely people who are willing and accustomed to reading. People's habits in reading can be a driving force for the development of high curiosity so that in the end they will gain broad insight. The habit of reading in individuals is a manifestation of the individual's high reading interest. Understanding reading interest according to Rachman (1983:16) is the embodiment of student reading behavior caused by certain driving factors, both by internal factors and external factors. Another definition of reading interest is put forward by F. Rahim (2008: 28) namely as a strong desire accompanied by one's efforts to read. The high interest in reading a person can be done by obtaining reading material through their own awareness or encouragement from outside.

The Community Reading corners Karangmojo Village has been used by the community, especially children, by reading in the courtyard of the mosque during their spare time, for example before reading the Koran in the afternoon. Karangmojo Village children when visiting reading corner still follow the health protocols recommended by the government, and do not huddle into one group. Books that have been borrowed and brought home by the community to be read at home, have been written on the Handy Library application with the status of borrowing books on behalf of the child who is borrowing the book and its membership number.

\section{CONCLUSION}

The construction of the Community Reading corners Karangmojo Village is located in the courtyard of the An-Nur Mosque, the location of this is the result of discussions with the head of the village and the mosque management. The provision of physical books for library of Karangmojo Village reached 350 books consisting of six categories, namely Children's Books, Natural Knowledge, General Knowledge, Religion, Entrepreneurship, and Archipelago Insights. The physical book lending system can be done online with an application called Handy Library. Provision of a Digital Library for Community Reading corners Karangmojo village is in the process of creating a web and training web admins. The community, especially children, have used the Community Reading corners Karangmojo Village facility while still following the recommended health protocols.

\section{REFERENCE}


RSF Conference Series: Business, Management and Social Sciences

Volume 1Number 4 (2021): 218-222

Increasing Public Interest on Reading through Physical and Digital Library in Karangmojo Village

Ratna Widyaningsih, Yudhy Widya Kusumo, Ristiyan Ragil Putradianto, Dewi Nur Khasanah, Intan Zuhaira

Zuliarso, Eri. Februaryyanti, Herny. (2013). Sistem Informasi Perpustakaan Buku Elektronik

Berbasis Web. Journal of Information Technology DYNAMIC Vol 18 No.1 January.

Saepudin, Asep. Nisa, Flowers. (2016). Menumbuhkan Minat Baca Masyarakat Melalui Taman

Bacaan Masyarakat Berbasis Teknologi Informasi. Kwangsan, Vol. 4 No. 1, June 2016 Edition. Pg: 43 54.

Astuti, Yuli. Nurasmi. (2013). Pengembangan Perpustakaan Digital di Universitas Riau dengan Program Library Management System (SLIMS). Echo Librarian Journal Vol. 1. No. 1. May 2013.

Raudah, Hildayati. (2012). Perpustakaan Digital Perpustakaan Masa Depan. Junal Iqra' Volume 06 No.02 October. Pg: 52-58

Irawan, Yudie. Mustafid. Sugiharto, Aris. (2011). Sistem Informasi Perpustakaan Berbasis Web

Aplication. Journal of Business Information Systems. Pg: 70-73.

Buku Pedoman Penyelenggaraan Taman Bacaan Masyarakat. (2006). Jakarta: Dikmas Directorate.

Rahmat, J. (2014). Peran PKBM dalam meningkatkan mutu pengelolaan program PAUDNI di Privinsi Jawa Tengah dan DI Yogyakarta. Journal of Pedagogy. Vol. 1 No. December 2, 2014.

Sutarno. 2008. Membina Perpustakaan Desa. Jakarta: Sagung Seto.

Sutisna, A. (2015). Pengembangan Model Bimbingan Teknis Berkelanjutan dalam Meningkatkan Kompetensi Tutor Paket C. Scientific Journal of VISION Vol. 10 No. December 2, 2015.

Rachman, A., et al. (1983). Minat Baca Murid Siswa Sekolah Dasar di Jawa Timur. Jakarta:

Center for Language Development and Development.

Rahim, F. (2008). Pengajaran Membaca di Sekolah Dasar. Jakarta: PT Bumi Aksara.

Kurniasih, Nunung. (2016). Optimalisasi Penggunaan Media Sosial untuk Perpustakaan. Proceedings of the National Seminar Papers. June. Pg: 1-9 